\title{
ANALISIS PENGUASAAN KONSEP IKATAN KIMIA PADA MATA KULIAH KIMIA ORGANIK MELALUI INSTRUMEN TWO TIER
}

Nurbaity dan Ine Mustikasari

Jurusan Kimia, Fakultas MIPA, Universitas Negeri Jakarta, Jl. Pemuda No. 10 Rawamangun Jakarta 13220, Indonesia

Email: nurbaity47@gmail.com

\begin{abstract}
Abstrak
Penelitian ini dilakukan di Program Studi Pendidikan Kimia FMIPA UNJ dengan tujuan menganalisis penguasaan konsep ikatan kimia pada mata kuliah kimia organik. Metode penelitian adalah metode deskriptif, subjek penelitian mahasiswa Pendidikan Kimia yang mengambil mata kuliah kimia organik I pada semester ganjil tahun ajaran 2010/2011. Instrumen yang digunakan adalah instrumen two tier untuk menganalisis penguasaan konsep mahasiswa pada ikatan kimia dan tes materi kimia organik menggunakan tes essai. Hasil penelitian menunjukkan bahwa penguasaan konsep mahasiswa pada materi ikatan kimia masih rendah, sekitar 28,50\% mahasiswa yang memahami konsep ikatan kimia, 31,50\% yang mengalami miskonsepsi, dan mengalami kesulitan sekitar $40 \%$. Pemberian pemantapan setelah menganalisis penguasaan pada materi ikatan kimia membantu dosen dalam merencanakan dan melaksanakan pembelajaran kimia organik yang efektif.
\end{abstract}

Kata kunci : Ikatan kimia, instrumen two tier

\begin{abstract}
The research was performed at Chemical Education FMIPA UNJ. The aim of the research was to analyze to understand the chemical bonding concept understanding on Organic Chemistry. The research method was descriptive with research subjects were chemical education students who registered to Organic Chemistry subject at odd semester year 2010/2011. The two tier instrument was applied for this research. Mean while, essay test was used to analyze Organic Chemistry concept understanding. The results showed that student's concept understanding on chemical bonding was remaining in low level. Approximately $28.50 \%$ of students were easy in understanding chemical bonding concept and around $31.50 \%$ of students were in misconception in chemical bonding. In addition, students acquired difficulties to understand the chemical bonding concept were about $40.00 \%$. Remedial was take after analyzing of chemical bonding concept, help lecturers in planning and teaching effective Organic Chemistry Lesson.
\end{abstract}

Key work ; Chemical bonding , two tier instrument

\section{A. PENDAHULUAN}

Pada perkuliahan Kimia Organik materi ikatan kima merupakan materi yang harus dikuasai oleh mahasiswa untuk mempelajari sifat-sifat fisik dan kimia dari suatu senyawa organik. Materi ikatan kimia ini telah dipelajari pada mata kuliah kimia dasar, namun mahasiswa masih kesulitan memahaminya. Menurut Levy Nahum dkk (2004), para siswa mendapat kesulitan dalam memahami konsep-konsep ilmu kimia yang bersifat abstrak.. Menurut Pendley, Bretz dan Novak (dalam Rahmawati, 2009) masalah-masalah umum yang ada dalam pembelajaran kimia adalah karena para siswa belajar dengan cara menghafal, para siswa tidak mengerti konsep serta keterkaitan satu sama lain konsepkonsep tersebut dan kesulitan untuk mengintegrasikan informasi-informasi baru dengan struktur kognitif mereka ketika pengetahuan yang sudah ada diintegrasikan dan tidak sesuai dengan pengalaman mereka. Seperti apa yang ditemukan oleh Ahtee dan Varjoli (dalam Jackson, 2001) bahwa hampir $10 \%$ siswa tingkat 8 di Finlandia tidak bisa membedakan antara zat/bahan dengan atom. Persentasi yang sama ditemukan juga di Sekolah Menengah atas dan tingkat Universitas, mereka melakukan kesalahan yang sama. Kimia organik mempelajari 
senyawa-senyawa kimia yang sangat banyak variasinya, struktur kimianya, sifat-sifat fisik, sifat- sifat kimia, serta mekanisme reaksi pada sintesa senyawa organik.

Untuk mempelajari ruang lingkup dalam perkuliahan kimia organik tersebut diperlukan penguasaan konsep ikatan kimia. Materi ikatan kimia lebih bersifat abstrak, biasanya lebih sulit untuk dipahami, keterkaitan dengan pemahaman materi sebelumnya yang relatif banyak seperti struktur atom, sifat-sifat keperiodikan unsur, sehingga kurang termotivasi dalam mempelajarinya. Hampir sebagian besar mahasiswa mempelajari ikatan kimia dengan cara menghafal, dimana kemampuan retensi informasi sangat kecil. Keadaan ini berpeluang munculnya berbagai miskonsepsi dalam pembelajaran kimia, oleh karena itu diperlukan suatu cara untuk mengidentifikasi miskonsepsi mahasiswa melalui tes kognitif awal menggunakan instrumen Two Tier.

Sehubungan dengan hal diatas, permasalahan penelitian ditujukan untuk memjawab pertanyaan berikut: (1) Bagaimanakah penguasaan konsep ikatan kimia mahasiswa pada perkuliahan kimia organik? 2) Bagaimana cara mengidentifikasi miskonsepsi mahasiswa pada konsep ikatan kimia ? 3) Apakah penggunaan instrumen Two Tier dapat mengidentifikasi penguasaan dan miskonsepsi yang dialami mahasiswa? 4) Bagaimana upaya mengurangi mengurangi miskonsepsi yang dialami mahasiswa ?

Mengacu permasalahan diatas maka tujuan penelitian ini adalah: 1) Untuk memperoleh informasi tentang penguasaan konsep dan miskonsepsi dan kesulitan yang dialami mahasiswa pada materi ikatan kimia sebagai dasar dalam mempelajari kimia organik,memahami struktur kimia organik, sifat-sifat kimia dan sifat-sifat fisika, serta mekanisme reaksi pada sintesis senyawa organik. 2) Untuk mengetahui apakah instrumen two tier dapat digunakan untuk mengidentifikasi miskonsepsi yang dialami mahasiswa? 2) Untuk mengetahui pengurangan miskonsepsi pada ikatan kimia setelah dilakukan alternatif pendekatan mengurangi miskonsepsi. Pada umumnya pelajaran kimia berhubungan dengan hal-hal yang bersifat abstrak di alam, yang terjadi melalui proses kimia dan merupakan wujud dari bagian yang sangat kecil. Banyaknya konsep abstrak dalam pengajaran kimia, memungkinkan adanya perbedaan pandangan antara siswa dan guru, keadaan inilah yang dikenal dengan miskonsepsi.

Fowler (dalam Suparno, 2005) memandang miskonsepsi "sebagai pengertian yang tidak akurat akan konsep, penggunaan konsep yang salah, klasifikasi contoh-contoh yang salah, kekacauan konsep-konsep yang berbeda, dan hubungan hierarkis konsep-konsep yang tidak benar". Seorang siswa yang memiliki miskonsepsi, akan mengalami kesulitan dalam mengembangkan konsep pada tingkat selanjutnya, yang pada akhirnya mengakibatkan minimnya minat belajar dan prestasi pada pelajaran kimia.

Miskonsepsi yang berulang, akan mengganggu konsepsi selanjutnya,oleh karena itu diperlukan identifikasi miskonsepsi pada siswa guna meningkatkan ketertarikan dan pemahaman siswa terhadap pembelajaran kimia, sehingga dihasilkan pembelajaran yang berkualitas dan efektif.

Miskonsepsi dalam bidang kimia banyak terjadi disebabkan oleh pemahaman pada diri mahasiswa sendiri, hal ini kemudian dikelompokan menjadi: prakonsep atau konsep awal mahasiswa, pemikiran asosiatif, pemikiran humanistik, penalaran yang tidak lengkap, intuisi yang salah, tahap perkembangan kognitif mahasiswa, kemampuan mahasiswa dan minat belajar mahasiswa. Selain itu penyebab miskonsepsi atau alternatif konsep dapat berasal dari guru yang mengajar, buku, dan metode mengajar. Untuk mendeteksi alternatif konsep atau 
Tabel 4.1 Data Pola Jawaban Hasil Tes pada Ikatan Kovalen dan Kovalen Polar

\begin{tabular}{|c|c|c|c|c|c|c|}
\hline \multirow{2}{*}{$\begin{array}{c}\text { No. } \\
\text { Soal }\end{array}$} & \multicolumn{5}{|c|}{ Pola Jawaban } \\
\cline { 2 - 7 } & Paham (BB) & \multicolumn{2}{|c|}{$\begin{array}{c}\text { Miskonsepsi } \\
\text { (BS) }\end{array}$} & $\begin{array}{c}\text { Tidak Paham } \\
\text { (SS) }\end{array}$ \\
\cline { 2 - 7 } & Jml & $\%$ & Jml & $\%$ & Jml & $\%$ \\
\hline 4 & 7 & $25.00 \%$ & 4 & $14.29 \%$ & 17 & $60.71 \%$ \\
\hline 12 & 5 & $17.86 \%$ & 8 & $28.57 \%$ & 15 & $53.57 \%$ \\
\hline 14 & 17 & $60.71 \%$ & 10 & $35.71 \%$ & 1 & $3.57 \%$ \\
\hline 19 & 9 & $32.14 \%$ & 5 & $17.86 \%$ & 14 & $50.00 \%$ \\
\hline 26 & 11 & $39.29 \%$ & 5 & $17.86 \%$ & 12 & $42.86 \%$ \\
\hline 28 & 18 & $64.29 \%$ & 4 & $14.29 \%$ & 6 & $21.43 \%$ \\
\hline 30 & 7 & $25.00 \%$ & 7 & $25.00 \%$ & 14 & $50.00 \%$ \\
\hline
\end{tabular}

miskonsepsi dapat dilakukan dengan beberapa cara yaitu: memberi tes diagnostik pada awal pelajaran, memberikan pertanyaan terbuka secara lisan kepada mahasiswa, mengoreksi langkah-langkah yang digunakan mahasiswa dalam menyelesaikan soal-soal essai, dan diskusi interaktif dalam kelas. Semakin beragam cara yang digunakan untuk mendeteksi mis konsepsi, akan semakin baik dalam mengungkap dimana letak dan peyebab miskonsepsi pada siswa. Penggunaan Two Tier tes diagnostik yang digabung dengan wawancara dan observasi, dapat mengidentifikasi miskonsepsi yang dialami siswa.

Instrumen Two Tier adalah suatu instrumen yang digunakan untuk mendiagnosa miskonsepsi yang dimiliki mahasiswa Instrumen ini dikembangkan oleh David F. Treagust (1988) Instrumen Two Tier memiliki kemampuan untuk mendorong berpikir analisis mahasiswa dalam memahami konsep. Selain itu instrumen Two Tier dapat digunakan untuk menguji pemahaman mahasiswa dan mendorong mereka untuk berpikir tentang konsep dibandingkan hanya fakta (Treagust \& Chandrasegaran, 2007). Instrumen Two Tier terdiri dari dua tahap, tahap pertama terdiri atas beberapa pilihan ( 2 sampai 4 pilihan) atas suatu obyek atau konsep yang akan dianalisis, sedangkan tahap kedua berisi kemungkinan alasan yang dipilih oleh mahasiswa.

\section{B. METODE PENELITIAN}

Metode yang digunakan dalam penelitian ini adalah deskriptif yang bersifat eksploratif bertujuan menggambarkan keadaan sekarang mengenai subjek yang diteliti. Penelitian dilaksanakan di Jurusan Kimia Fakultas Matematika dan IImu Pengetahuan Alam (MIPA) Universitas Negeri Jakarta .

Tabel 4.2: Data Pola Jawaban Hasil Tes pada Struktur Lewis Dalam Senyawa

\begin{tabular}{|c|c|c|c|c|c|c|}
\hline \multirow{2}{*}{$\begin{array}{c}\text { No. } \\
\text { Soal }\end{array}$} & \multicolumn{6}{|c|}{ Pola Jawaban } \\
\cline { 2 - 7 } & \multicolumn{2}{|c|}{ Paham (BB) } & \multicolumn{2}{|c|}{$\begin{array}{c}\text { Miskonsepsi } \\
\text { (BS) }\end{array}$} & $\begin{array}{c}\text { Tidak Paham } \\
\text { (SS) }\end{array}$ \\
\cline { 2 - 7 } & Jml & $\%$ & Jml & $\%$ & Jml & $\%$ \\
\hline 7 & 7 & $25.00 \%$ & 18 & $64.29 \%$ & 3 & $10.71 \%$ \\
\hline 15 & 9 & $32.14 \%$ & 9 & $32.14 \%$ & 10 & $35.71 \%$ \\
\hline
\end{tabular}

Subjek penelitian adalah mahasiwa jurusan pendidikan kimia semester $\mathrm{V}$ tahun ajaran 2010/2011 sebanyak 28 orang yang mengambil mata kuliah kimia organik. Alur Penelitian dimulai dari a) menganalisis konsepkonsep pada materi ikatan kimia sebagai dasar dalam mempelajari kimia organik.; b) membuat instrumen two tier untuk mengetahui penguasaan mahasiswa pada konsep ikatan kimia dan mengidentifikasi miskonsepsi dan kesulitan yang dialami mahasiswa setelah mempelajari kimia dasar: c) melakukan uji validitas tes dengan ahli: d) melakukan tes tertulis menggunakan instrumen two tier ; e) wawancara untuk 
Tabel 4.3: Data Pola Jawaban Hasil Tes pada Hibridisasi

\begin{tabular}{|c|c|c|c|c|c|c|}
\hline \multirow{2}{*}{$\begin{array}{c}\text { No. } \\
\text { Soal }\end{array}$} & \multicolumn{5}{|c|}{ Pola Jawaban } \\
\cline { 2 - 7 } & \multicolumn{2}{|c|}{ Paham (BB) } & \multicolumn{2}{|c|}{ (BS) } & \multicolumn{2}{c|}{ (SS) } \\
\cline { 2 - 7 } & Jml & $\%$ & Jml & $\%$ & Jml & $\%$ \\
\hline 9 & 2 & $7.14 \%$ & 7 & $25.00 \%$ & 17 & $60.71 \%$ \\
\hline 17 & 0 & $0.00 \%$ & 5 & $17.86 \%$ & 23 & $82.14 \%$ \\
\hline 25 & 7 & $25.00 \%$ & 5 & $17.86 \%$ & 16 & $57.14 \%$ \\
\hline 29 & 2 & $7.14 \%$ & 7 & $25.00 \%$ & 19 & $67.86 \%$ \\
& & & & & & \\
\hline
\end{tabular}

memperoleh informasi pemahaman mahasiswa pada konsep ikatan kimia berdasarkan alasan dari jawaban yang dipilih; f) data hasil tes dan wawancara dianalisis untuk memperoleh gambaran penguasaan materi ikatan kimia; g) dari hasil analisis dirancang pembelajaran untuk pemantapan konsep-konsep yang belum dikuasai dan mengurangi miskonsepsi yang dialami mahasiswa; h) melakukan tes hasil belajar kimia organik dalam bentuk tes essai; i) menganalisis hasil tes dan menyimpulkan.

Tabel 4.4: Data Pola Jawaban Hasil Tes pada Ikatan Hidrogen

\begin{tabular}{|c|c|c|c|c|c|c|}
\hline \multirow{2}{*}{$\begin{array}{c}\text { No. } \\
\text { Soal }\end{array}$} & \multicolumn{6}{|c|}{ Pola Jawaban } \\
\cline { 2 - 7 } & \multicolumn{3}{|c|}{ Paham (BB) } & \multicolumn{2}{|c|}{ (BS) } & \multicolumn{2}{c|}{ (SS) } \\
\cline { 2 - 7 } & Jml & $\%$ & Jml & $\%$ & Jml & $\%$ \\
\hline 16 & 5 & $17.86 \%$ & 12 & $42.86 \%$ & 11 & $39.29 \%$ \\
\hline 24 & 5 & $17.86 \%$ & 10 & $35.71 \%$ & 13 & $46.43 \%$ \\
& & & & & & \\
\hline
\end{tabular}

Teknik pengumpulan data dilakukan sebagai berikut:a) melakukan tes kogmnitif awal berupa tes tertulis, b) wawancara pada mahasiswa untuk mendapat informasi dari jawaban yang dipilih beserta alasannya. c) tugas-tugas dalam pembelajaran setelah pemantapan , d) melakukan tes tertulis dalam bentuk essai pada materi kimia organik, e) mengolah data hasil penelitian

Tehnik pengolahan data dilakukan sebagai berikut:1) memeriksa dan menentukan skor Jawaban pada tes kognitif awal dalam bentuk soal Two Tier, benar atau salah dengan memberikan alasan. Diberi skor 1 bila jawaban benar dan alasan benar, skor 0 bila jawaban benar alasan salah atau kedua duanya salah. 2) menghitung skor total setiap mahasiswa dengan menjumlahkan skor masing-masing soal. 3) membuat tabel skor mahasiswa. 4) menganalisis alasan jawaban yang dikemukakan oleh mahasiswa yang pada masing-masing indikator dan menentukan apakah mahasiswa sudah memahami konsep (BB) jawaban benar alasan benar, miskonsepsi (BS) jawaban benar alasan salah, dan tidak memahami konsep.(SS) jawaban salah alasan salah. 5) menyusun data yang diperoleh kedalam bentuk tabel .6) menggambarkan data dalam bentuk grafik 7) menganalisis hasil tes hasil belajar materi kimia organik.

\section{HASIL DAN PEMBAHASAN}

\section{Penguasaan Mahasiswa Pada Konsep Ikatan Kimia}

Berdasarkan data yang diperoleh dari hasil tes tertulis kognitif awal dari 28 orang mahasiswa pada materi ikatan kimia. Untuk menganalisis penguasaan mahasiswa pada materi ikatan kimia dan mengidentifikasi miskonsepsi serta kesulitan yang dialami mahasiswa, diawali dengan pengolahan skor dari hasil uji instrumen Two Tier berupa pilihan Benar Salah dengan memberikan alasan dari jawaban yang dipilih. Dari hasil pengolahan data skor, penguasaan konsep mahasiswa dibagi dalam 
tiga kategori yaitu paham konsep (BB) ,miskonsepsi (BS) dan tidak paham (SS) Ruang lingkup materi tes kognitif awal untuk mengetahui penguasaan mahasiswa pada konsep ikatan kimia dalam mempelajari kimia organik, konsep-konsep yang diujikan dibagi menjadi 7 kelompok yaitu: a) Konsep Sistem Periodik Unsur, b) Konsep Ikatan Kovalen dan Kovalen Polar. c) Konsep Energi ikatan dan Panjang Ikatan . d) Konsep Struktur Lewis . e) Konsep Hibridisasi. f) Konsep Ikatan Ion. g) Konsep Ikatan Hidrogen

\section{a. Analisis Pemahamam/ Miskonsepsi Mahasiswa pada konsep Ikatan Kovalen dan Kovalen Polar}

Dari data Tabel 4.1 terlihat pola jawaban mahasiswa yang mengalami miskonsepsi (BS) , tidak paham (SS) dan yang paham (BB), soal yang dianggap paling sulit adalalah nomor $4,12,19$, dan 30 , hanya sekitar $25 \%$ siswa yang menjawab benar. Untuk soal nomor 12 tentang molekul kovalen polar, jumlah yang miskonsepsi dan yang tidak paham mencapai 23 orang $(82,14 \%)$.

Dari alasan yang diberikan pada jawaban, mahasiswa tidak dapat membedakan senyawa polar dan non polar,kaitan momen dipol dengan kepolaran, mahasiswa beranggapan bahwa molekul non polar tidak memiliki unsur yang bersifat elektronegatif. Belum bisa membedakan konsep ikatan kovalen dengan kovalen polar. Kaitan keelektonegatifan unsurunsur yang membentuk ikatan dan kedudukan atom-atom dalam molekul yang akan menentukan momen dipole belum dipahami secara benar.

Sebenarnya konsep polar dan non polar didasarkanpada perbedaan keelektronegatifan unsur-unsur yang berikatan dalam suatu senyawa atau molekul yang menghasilkan momen dipol yang berbeda dengan kepolaran yang berbeda pula. Molekul-molekul yang unsur-unsur yang berikatan mempunyai perbedaan keelektronegatifan yang besar seperti $\mathrm{CCL}_{4}$ adalah termasuk molekul non polar karena jumlah momen dipole $=0$, Jadi pada molekul non polar ada kemungkinan terdapat ikatan polar.

Untuk membandingkan kepolaran senyawa $\mathrm{FI}$ dengan $\mathrm{FCl}$, mereka melihat dari perbedaan keelektronegatifan antara I dan $\mathrm{Cl}$ dimana $\mathrm{Cl}$ lebih elektronegatif dari I, sebenarnya yang menentukan kepolaran adalah perbedaan keelektronegatifan dari atom-atom yang berikatan. Jadi $\mathrm{FI}$ lebih polar dari $\mathrm{FCl}$, jadi miskonsepsi pada pengertian kepolaran. Tidak bisa mengaplikasikan sifat-sifat unsur dalam sistem periodik seperti kepolaran senyawa $\mathrm{FI}$ dan $\mathrm{FCl}$, tidak bisa mengaitkan dengan sifat keelektronegatifan unsur dalam sistem periodik. Mereka bingung menggunakan konsep ketika menjawab soal.

\section{b. Analisis Pemahaman/ Miskonsepsi}

Mahasiswa Pada Konsep Struktur Lewis

Berdasarkan data pola jawaban dari Tabel 4.2 , menggambarkan banyak mahasiswa yang belum paham atau miskonsepsi dan tidak paham atau kesulitan dalam mempelajari konsep struktur Lewis. Mahasiswa yang menjawab benar kedua soal ini masih sedikit 7-9 orang ( jumlah 28 orang).

Dari alasan yang diberikan, terlihat bahwa mahasiswa belum memahami adanya penyimpangan dari aturan oktet yang dikembangkan oleh lewis, sehingga mereka beranggapan semua senyawa dipastikan memenuhi aturan oktet, seperti $\mathrm{PCl}_{5}$ dan $\mathrm{BF}_{3}$. $\mathrm{PCl}_{5}$.

Hal ini dapat dijelaskan bahwa atom $\mathrm{P}$ mempunyai 5 elektron valensi dalam struktur Lewis $\mathrm{PCl}_{5}$ memilki 10 elektron yang dipakai bersama bukan delapan, Lewis menyatakan sebagai suatu penyimpangan dari oktet dan menggolongkannya ke dalam oktet yang diperluas. Untuk $\mathrm{BF}_{3}$, unsur yang mempunyai 3 elektron valensi, dalam senyawa $\mathrm{BF}_{3}$ terdapat 6 elektron valensi yang dipakai bersama, Lewis menyatakan sebagai suatu 
penyimpangan dan digolongkan kedalam oktet yang tidak sempurna. Jadi bearti tidak semua senyawa yang ditemukan memenuhi aturan oktet.

\section{c. Analisis Pemahaman/ Miskonsepsi \\ Mahasiswa pada Konsep Hibridisasi.}

Berdasarkan pola jawaban data dari Tabel 4.3 , menggambarkan cukup banyak mahasiswa yang belum paham atau miskonsepsi dan tidak paham atau kesulitan dalam mempelajari konsep hibridisasi . Semua soal ini $(9,17,25,29)$ dianggap paling sulit, hanya sekitar $10 \%$ mahasiswa menjawab benar,soal nomor 17 sebanyak 23 orang (82,14\%) tidak paham dan 5 orang $(17,86 \%)$ yang mengalami miskonsepsi. Dari alasan alasan yang diberikan, mahasiswa belum memahami pembentukan ikatan phi dan sigma dalam senyawa organik. Mereka memahami bahwa atom $C$ mempunyai 4 elekton terluar $2 s^{2} 2 p^{2}$, elektron ini yang digunakan untuk membentuk senyawa $\mathrm{CH}_{4}$. Bearti mahasiswa belum mengaitkan pembentukan senyawa $\mathrm{CH}_{4}$ melalui proses hibridisasi.

Ikatan kovalen terbentuk karena pemakaian bersama sepasang elektron dalam orbital yang sama. Atom C mempunyai sepasang electron pada orbital $2 s$ dan satu electron masing-masing pada orbital $2 \mathrm{p}$. Untuk membentuk ikatan kovalen hanya tersedia 2 orbital $2 p$ yang akan mengikat dua atom $\mathrm{H}$, kenyataannya atom $\mathrm{C}$ dapat membentuk $\mathrm{CH} 4$ karena terjadinya hibridisasi $\mathrm{sp}^{3}$.

Konsep mereka tentang pembentukan ikatan sigma melalui tumpang tindih orbital s, mereka beranggapan bahwa ikatan sigma terbentuk hanya untuk unsur-unsur yang memiliki orbital $\mathrm{s}$, misalnya untuk $\mathrm{H}$ dan $\mathrm{H}$ yang membentuk $\mathrm{H}-\mathrm{H}$, Sedangkan untuk unsur yang berbeda seperti $\mathrm{C}-\mathrm{H}$, ikatan sigma yang terbentuk antara orbital $\mathrm{sp}^{3}$ dan $\mathrm{s}$, begitu pula untuk ikatan sigma rangkap C --
C $\quad\left(s p^{2}-s p^{2}\right)$, dan ikatan sigma yang terbentuk antara $\mathrm{sp}-\mathrm{sp}$.

d. Analisis Pemahaman/ Miskonsepsi Mahasiswa pada Konsep Ikatan Hidrogen

Berdasarkan data pola jawaban dari Tabel 4.4 , menggambarkan banyak mahasiswa yang belum paham atau miskonsepsi dan tidak paham atau kesulitan dalam memahami konsep ikatan hidrogen. Ke dua soal ini $(16,24)$ dianggap sulit karena 23 mahasiswa (82,14\%) dari 28 mahasiswa menjawab salah (BS adan SS). Dari alasan-alasan yang diberikan, mahasiswa beranggapan ikatan hidrogen lebih kuat dari ikatan kovalen, karena mahasiswa masih beranggapan bahwa energi ikatan ditentukan oleh perbedaan kelektronegatifan. Konsep Ikatan hidrogen adalah terbentuknya muatan parsial positif dan negatif dari hidrogen yang berikatan dengan unsur-unsur yang mempunyai keelektonegatifan yang cukup besar seperti N, O, dan F. Ikatan hidrogen yang terbentuk merupakan interaksi muatan parsial positif dan parsial negatif sehingga ikatannya lemah. Berbeda dengan ikatan kovalen dimana merupakan pemakaian bersama sepasang elekron secara maksimal menghasilkan ikatan yang kuat.

Mengenai titik didih, mahasiswa beranggapan bahwa titik didih hanya dipengaruhi oleh massa molekul sehingga mengatakan titik $\mathrm{H}_{2} \mathrm{~S}$ lebih tinggi dari titik didih air, mahasiswa yang menjawab benar hanya 5 mahasiswa $(17,86 \%)$

Hal ini dapat dijelaskan karena titik didih dipengaruhi oleh bermacam macam faktor antara lain massa molekul, struktur molekul, kerapatan atau fasa dan ikatan hidrogen, Untuk $\mathrm{H}_{2} \mathrm{O}$ massa molekul kecil dari $\mathrm{H}_{2} \mathrm{~S}$ tetapi $\mathrm{H}_{2} \mathrm{O}$ dapat membentuk ikatan hidrogen sedangkan $\mathrm{H}_{2} \mathrm{~S}$ tidak membentuk ikatan hidrogen, sehingga menyebabkan titik didih air lebih besar dari $\mathrm{H}_{2} \mathrm{~S}$. 


\section{Analisis Hasil Tes Kimia organik}

Berdasarkan hasil tes kimia organik (setelah diberi pemantapan konsep ikatan kimia) pada materi alkohol, alkil halida, aldehid dan keton, yang terdiri dari 6 soal essai. Terdapat 3 soal yaitu soal nomor 1,3 dan 5 memerlukan penguasaan konsep ikatan untuk menjawab soal tersebut dengan benar.

Pada soal no 1 diharapkan mahasiswa sudah memahami tentang konsep keelektronegatifan dan bagaimana pengaruh ikatan rangkap pada reaktifitas suatu alkil halida. Reaksi $\mathrm{SN}_{2}$ atau disebut sebagai substitusi nukleofilik bimolekuler, merupakan reaksi serentak dari suatu alkil halida dengan nukleofil. Laju reaksi ditentukan oleh kedua spesi ini, sehingga laju reaksi dikatakan order kedua. Di tinjau dari alkil halida, maka laju reaksi ditentukan oleh struktur alkil halida Pemahaman mahasiswa terhadap konsep keelektronegatifan memudahkan mahasiswa untuk membedakan gugus pergi yang baik (Good Leaving Group) atau gugus pergi yang buruk (Bad Leaving Group). Halogen adalah termasuk gugus pergi yang baik. Faktor lain yang menentukan kereaktifan alkil halida dalam reaksi $\mathrm{SN}_{2}$ adalah kedudukan halogen dalam senyawa alkil halida. Alkil halida dalam posisi primer lebih cepat laju reaksinya dibandingkan alkil halida sekunder, begitu juga dengan alkil halida tersier hampir tidak terbentuk reaksi $\mathrm{SN}_{2}$. Untuk alkil halida primer, laju reaksi $\mathrm{SN}_{2}$ dipengaruhi lagi oleh jumlah atom karbon atau panjang rantai. Dengan bertambahnya panjang rantai maka laju reaksi akan semakin rendah.

Adanya ikatan rangkap pada gugus alkil, seperti alilik dan benzilik juga mempengaruhi laju reaksi. Dengan pemahaman mahasiswa terhadap hibridisasi $\mathrm{sp}^{2}$ perbedaan tersebut mudah ditetapkan. Dari soal nomor 1 ini rerata skor 7,53 (skor maksimal 10) Pada soal no.3, mahasiswa dapat memberikan jawaban secara benar apabila mahasiswa memahami konsep pembentukan ikatan hidrogen, dan syarat-syarat yang diperlukan untuk terbentuknya ikatan hidrogen.

Dengan terbentuknya ikatan hidrogen antar molekul atau inter molekul akan menyebabkan kenaikan titik leleh suatu senyawa. Senyawa glikol $\left(\mathrm{HOCH}_{2} \mathrm{CH}_{2} \mathrm{OH}\right)$ dapat membentuk ikatan hidrogen sedangkan senyawa dilkloretan $\left(\mathrm{ClCH}_{2} \mathrm{CH}_{2} \mathrm{Cl}\right)$ tidak dapat membentuk ikatan hidrogen. Dari hasil tes untuk soal nomor 3 ini, rerata skor yang diperoleh mahasiswa sebesar 13,56 ( skor maksimal 20) Pada soal no.5, pemahaman mahasiswa terhadap ikatan kovalen non polar, ikatan kovalen polar, kovalen koordinasi, dan keelektronegatifan atomatom, akan memudahkan mahasiswa dalam meyelesaikan mekanisme reaksi yang diberikan secara benar.

Gugus karbonil $(-\mathrm{C}=\mathrm{O})$ adalah gugus yang terbentuk dari dua atom yang mempunyai perbedaan keelektronegatifan yang cukup besar. Perbedaan keelektronegatifan ini memungkinkan terbentuknya atom karbon dengan muatan parsial positif dan atom oksigen dengan muatan parsial negatif. Kondisi dimana atom $\mathrm{C}$, mengemban muatan parsial positif, akan mudah diserang oleh suatu nukleofil, yaitu ion, atau molekul netral yang mempunyai pasangan elektron bebas, sehingga terbentuk ikatan kovalen koordinasi.

Dari hasil tes soal nomor 5 ini rerata skor yang diperoleh mahasiswa sebesar 12,44 atau (skor maksimal 20) atau. Rerata skor secara keseluruhan ( soal nomor 1,3, dan 5) sebesar 33,53 (total skor maksimum 50 ) atau $67,06 \%$.

\section{SIMPULAN DAN SARAN}

Berdasarkan analisis data hasil penelitian dan pembahasan, dapat ditarik kesimpulan sebagai berikut :

1. Secara keseluruhan rerata penguasaan mahasiswa pada kosep ikatan kimia masih rendah, dan mengalami miskonsepsi dan kesulitan memahami cukup tinggi pada 
konsep ikatan kimia menggunakan instrumen two tier

2. Konsep materi ikatan yang paling sukar adalah konsep hibridisasi, rerata mahasiswa yang dapat menjawab dan memberi alasan dengan benar sebesar $9,82 \%$

Konsep materi ikatan kimia yang paling banyak mengalami miskonsepsi adalah konsep Lewis /aturan oktet, rerata $48,21 \%$ mahasiswa dapat menjawab dengan benar tetapi alasan yang diberikan salah.

3. Konsep materi ikatan kimia yang paling tidak dipahami atau sulit bagi mahasiswa adalah konsep hibridisasi, sekitar 67\% mahasiswa menjawab salah dan alasan salah.

4. Hasil belajar kimia organik setelah pemantapan konsep ikatan kimia, diperoleh skor $67,06 \%$ ( khusus soal yang jawabannya menggunakan penguasaan konsep ikatan kimia), bearti pemantapan konsep ikatan kimia setelah analisis penguasaan konsep melalui instrumen two tier dapat meningkatkan pemahaman mahasiswa pada materi kimia organik khususnya materi alkohol, alkil halida, aldehid dan keton.

Berdasarkan kesimpulan di atas, dapat dikemukakan beberapa saran sebagai berikut:

1. Mengingat masih besarnya prosentase mahasiswa yang mengalami miskonsepsi dan kesulitan pada konsep ikatan kimia, diharapkan dosen meningkatkan kualitas pembelajarannya dengan menggunakan metode yang bervariasi

2. Melakukan penelitian yang sama pada mata kuliah lain untuk mengetahui penguasaan mahasiswa pada konsep materi yang diperlukan untuk memahami materi selanjutnya menggunakan instrumen two tier.

3. Melakukan penelitian lanjutan bagaimana menangani miskonsepsi yang dialami siswa melalui penelitian tindakan kelas .

\section{DAFTAR PUSTAKA}

Chandrasegaran, T 2007 Diagnostic Assesment of Secondary Student's use of Three Levels of Representation to Explain Simple Chemical Reactions. Paper presented at $36^{\text {th }}$ annual conference of the Australsian Science Education Association (ASERA). Hamilton: New Zealand.

Jackson, J. 2001. Student Preconception and Missconception in Chemistry. Dept. of Physic and Astronomy: Arizona State University. http://assessmentws.wilkispaces.com/file/view/chemistry-misconception.pdf. 16 Maret 2009, pukul13:34.

Levy, N. 2004. Can Final Examination Amplify Students' Misconception in Chenistry?. Chemistry Education: Research and Practice, 5 (3). 301-325.

Rahmawati, Y. 2009. Probing for Students' Understanding $n$ Chemistry Using Multiple Approaches. Curtin of University: Australia.

Suparno. 2005, Miskonsepsi dan Perubahan Miskonsepsi dalam Pembelajaran Fisika. Grasindo: Jakarta.

Treagust, D. 1988. The Development and Uses of Diagnostic Instrument to Science Education, 10, 159-169. 